\title{
Commentary
}

\section{E-Learning Among University Students During COVID-19}

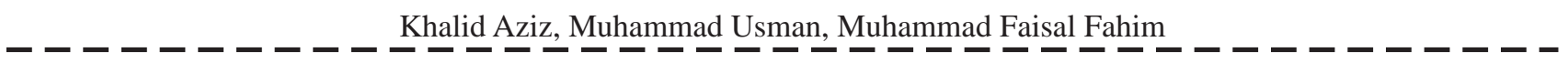

How to cite this Article:

Aziz K, Usman M, Fahim MF. E-learning Among University Students During COVID-19. J Bahria Uni Med Dental Coll. 2020; 10(4): 325-326 DOI: https://doi.org/ 10.51985/JBUMDC2020054

Somewhere in the beginning of March 2020, State Government suddenly announced the closure of all educational institutions as a preventive measure to restrict the spread of novel coronavirus. It has been over five months since the government has completely shut down the educational institutions. Recently there is an announcement that Universities will reopen in the mid of September 2020. As the days pass by with no instant solution to stop the outbreak of covid-19, the educational processes came to a standstill due to closure of the universities and colleges. In order to restore the ongoing process of learning majority universities in Pakistan have now quickly shifted to elearning. This pandemic has transformed the old methods of teaching with the new technology driven methods.

E-learning according to a research is electronically enabled learning. ${ }^{1}$ It includes the use of information and communication technologies to get access to online teaching or learning resources. Simply the digital technology driven learning is called e-learning. Few researchers have further narrowed down the definition by referring any learning that is enabled by web or internet. ${ }^{2,3}$

Researches have described two modes of e-learning 'synchronous' or 'asynchronous' depending upon the timing of interaction. The synchronous timing allows interaction between instructor and learners or between learners. ${ }^{4}$ The asynchronous timing also allows interaction with the instructor or between learners at different times. ${ }^{5}$

The adoption of e-learning among university students has several advantages and limitations. Benefits of e-learning are:

1. It is flexible. Students have the choice of choosing the time and place that suits them. ${ }^{6}$

Khalid Aziz
Vice Principal
Bahria University College of Physical Therapy
Bahria University Medical \& Dental College
Muhammad Usman
Senior Lecturer
Bahria University College of Physical Therpay
| Bahria University Medical \& Dental College
Muhammad Faisal Fahim | | | |
| Researcher \& Senior Lecturer Biostatistics
| Bahria University College of Physical Therpay
| Emaia University Medical \& Dental College
| Received: 23-Jul-2020
| Accepted: 23-Sep-2020

2. Students are not required to travel to their institutions it is therefore cost effective. It can cater maximum number of students without the need of new buildings and classrooms.

3. Synchronous type of e-learning method allows for discussion among instructors and students at the same time through different tools such as videoconference or chat rooms. Thus offers instantaneous feedback. ${ }^{5}$

4. Asynchronous type of e-learning allows students to study at their own pace, slow or quick. It therefore decreases stress among students who are slow learners. ${ }^{7,8}$

5. E-learning offers ease of access to a plethora of information that is available online.

There are some limitations of e-learning as well.

1. E-learning doesn't offer much when it comes to improving communication skills. Student might lack the essential skills to deliver the knowledge to others despite having excellent academic record.

2. Asynchronous type of e-learning allows interaction through thread discussion or via emails, therefore it lacks interaction at the same moment and the instructors are not able to receive instant feedback from students and vice versa. $^{5}$

3. It is difficult to control cheating.

4. E-learning is not an appropriate technique of education especially in those scientific fields which include practical work as well. Therefore researchers are of the opinion that e-learning is beneficial for social science and humanities and offers limited benefits in fields where practical skills are of utmost importance like medical science, pharmacy, and physiotherapy.

5. Heavy use of some websites make them congested, as well as some websites require monthly subscriptions which may lead to unanticipated loss of time and money., ${ }^{9}$ COVID-19, was revealed in December 2019. ${ }^{11}$ Face to face transmission was discovered by clinical analysis. ${ }^{12-14}$. This outbreak has imposed an online platform in all aspects of human life such as business, marketing, educational institutes. ${ }^{15}$

\footnotetext{
Author Contribution:

Khalid Aziz: Supervision of work and Manuscript

I Muhammad Usman: Conceived the study and Manuscript |

| Muhammad Faisal Fahim: Topic selection of research, Help |

in creating sequence in the manuscript, Editing and submission ।

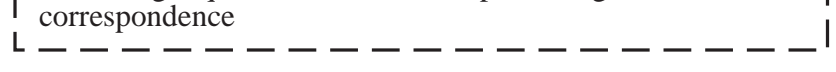


In educational institutes; the E-learning involves digital tools for learning as well as teaching which comes with the ease of studying anywhere and anytime. Despite some challenges e-learning has a strong impact in teaching and learning. Its full implementation in universities will allow students, faculty members and administrators to enjoy its benefits.

\section{REFERENCES:}

1. Abbad MM, Morris D, De Nahlik C. Looking under the bonnet: Factors affecting student adoption of e-learning systems in Jordan. International Review of Research in Open and Distributed Learning. 2009;10(2).

2. Gernsbacher MA. Why internet-based education?. Frontiers in psychology. 2015;5:1530.

3. Keller, C. \& Cernerud, L. Students' perception of e-learning in university education. Learning, Media and Technology.2002; 27(1): 55-67.

4. Algahtani, A.F. Evaluating the Effectiveness of the E-learning Experience in Some Universities in Saudi Arabia from Male Students' Perceptions, Durham theses, Durham University. 2011

5. Almosa, A. \& Almubarak, A. E-learning Foundations and Applications, Saudi Arabia: Riyadh 2005

6. Smedley, J.K. Modelling the impact of knowledge management using technology. OR Insight (2010) 23, 233-250.

7. Pham L, Limbu YB, Bui TK, Nguyen HT, Pham HT. Does e-learning service quality influence e-learning student satisfaction and loyalty? Evidence from Vietnam. International Journal of Educational Technology in Higher Education. 2019;16(1):7.
8. O’Doherty D, Dromey M, Lougheed J, Hannigan A, Last J, McGrath D. Barriers and solutions to online learning in medical education-an integrative review. BMC medical education. 2018;18(1):130.

9. Kundi GM, Nawaz A, Khan S. The predictors of success for e-learning in higher education institutions (HEIs) in N-W.F.P, Pakistan. Journal of Information Systems and Technology Management. 2010; 7(3): 545-578

10. Klein, D. \& Ware, M. E-learning: new opportunities in continuing professional development. Learned publishing. 2003; 16 (1) 34-46

11. Huang, C., Wang, Y., Li, X., Ren, L., Zhao, J., Hu, Y., Zhang, L. et al. Clinical features of patients infected with 2019 novel coronavirus in Wuhan, China. The Lancet. 2020; 395(10223): 497-506. https://doi.org/10. 1016/S0140-6736(20)30183-5

12. Li, Q., Guan, X., Wu, P., Wang, X., Zhou, L., Tong, Y., Ren, R., Leung, K. S., Lau, E. H., Wong, J. Y., \& Xing, X. Early transmission dynamics in Wuhan, China, of novel coronavirus-infected pneumonia. New England Journal of Medicine.2020; 382: 1199-1207. https://doi.org/10 .1056/ NEJMoa2001316

13. Paules, C. I., Marston, H. D., \& Fauci, A. S. (2020). Coronavirus infections - more than just the common cold. Jama, 323(8), 707-708. https://doi.org/10. 1001/jama. 2020.0757

14. Wang, C., \& Zha, Q. Measuring systemic diversity of Chinese universities: A clustering-method approach. Quality \& Quantity. 2018; 52(3), 1331-1347. https://doi.org/10.1007/ s11135017-0524-5

15. Merriam-Webster Online Dictionary. (2020, April 21). Definition of pandemic. https://www.merriam-webster.com/ dictionary/pandemic 